\title{
Witnesses of the Time: A survey of clock rooms, clock towers and façade clocks in Istanbul in the Ottoman Era*
}

\author{
Kaan ÜÇSU \\ Istanbul Üniversitesi
}

Measuring and communicating time has been an important activity for the Ottomans, both in the Classic Age and in the Age of Reforms. This article aims to examine timekeeping constructions such as clock rooms (hereafter muvakkithanes in plural), tower clocks and façade clocks in Istanbul, a cosmopolitan city and the seat of the Ottoman Court. It traces the emergence and diffusion of tower clocks and the coexistence of muvakkithanes and tower clocks in the nineteenth and early twentieth century. The account is based on unused archival documents, newly published studies as well as a foot expedition. Besides, it takes into account façade clocks embedded in public buildings that have been omitted in the existing works on this topic. By doing this, it attempts at giving a complete account of the time-indicating constructions of Istanbul.

Time-indicating constructions have been subject to various studies for the last half century. In 1971, historian of medicine and Ottoman culture Süheyl Ünver (18981986) presented a seminal paper at the ninth Atatürk Conference, on the role of clock rooms among the Ottoman Turks. ${ }^{1}$ Although its title seems to indicate that the paper addresses the muvakkithanes in general, it focuses on the muvakkithanes of Istanbul. Ünver lists an aggregate of 69 muvakkithanes, 38 of which had disappeared. He gives information on their date of construction, donors, architecture and current situation. Even though he does not provide a bibliography of his work, he appears to have consulted with Ottoman archives, witnesses and made afoot survey. Ünver presented another paper on muvakkithanes at the International Symposium on the Observatories in Islam, in 1980, which focused on the relation between müneccimbaşılık (the post of head astrologer) and muvakkithane. ${ }^{2}$

For more than a decade, these two papers did not trigger new studies on the topic. In 1993, Salim Aydüz completed his MA thesis on the institution of müneccimbaşılı in which he briefly examined the tasks of muvakkithanes and muvakkits. ${ }^{3}$ Later, he extended this section, adding information on several famous

Article received in 18-11-2017 and admitted to publication in 31-12-2017.

*. This article is based on my MA thesis approved in 2011 by Istanbul University, Institute of Social Sciences. I would like to thank anonymous reviewers, Darina MARTYKÁNOVÁ and Banu KAYIR for their comments.

1. Süheyl ÜNVER, “Osmanlı Türkleri İlim Tarihinde Muvakkithaneler”, in Atatürk Konferansları 19711972, Ankara,Türk Tarih Kurumu Basımevi, 1975, pp. 217-259.

2. Süheyl ÜNVER, “İstanbul Muvakkithaneleri Vazifelerinin İlmî ve Kültürel Değerleri Üzerine”, in M. DIZER (ed.), International Symposium on the Observatories in Islam, 19-23 September 1977), Istanbul, Millî Eğitim Basımevi, 1980, pp. 45-51. For further information see Salim AYDÜz, "Osmanlı Asronomi Müesseseleri”, Türkiye Araştırmaları Literatür Dergisi, 2/4 (2004), pp. 411-453.

3. Salim AYDÜZ, "Osmanlı Devleti’nde Müneccimbaşllık", Osmanlı Bilimi Araştırmaları, in Feza GÜNERGUN (ed.), İstanbul, İstanbul Üniversitesi Yayınlar1, 3.911 (1995), pp. 159-207. 


\section{ÜÇSU Witnesses of the Time}

muvakkits and their works. ${ }^{4}$ However, these two works of Aydüz do not add much information to what Ünver provided, except for dwelling more on the institutional dimensions of muvakkithanes and on the astronomical works of some muvakkits.

Since then, muvakkithanes mostly drew the attention of art historians and historians of architecture. Art historian Server Dayığlu published an article in a popular magazine on Istanbul in 1995 and went on to make a book out of it more than a decade later. ${ }^{5}$ Historian of architect Zeliha Kumbasar finished her MA thesis on the muvakkithanes of Istanbul in 2008. ${ }^{6}$ Unsurprisingly, both studies examine artistic and architectural features of the muvakkithanes, report on their present situation and rely heavily on Ünver's work. Neither of them adds anything of importance with regard to donors and construction dates. However, Kumbasar provides information regarding relevant documents in the Ottoman archives, albeit without using them herself.

In a similar vein, it was mostly art historians who first showed interest in clock towers across the Ottoman Empire. Hakk1 Acun examines the ones that still exist in terms of their artistic characteristics, construction dates and donors in his book on clock towers of the Empire. ${ }^{7}$ While his account includes both independent clock towers and the ones attached to the body of buildings including parts in the countenance of tower, it excludes façade clocks. He understands clock towers as means of secularizing the state. Considering that the assessment of clock towers as means of secularization of the state cannot fully explain the complex nature of the issue, Klaus Kreiser emphasises, in his preliminary survey of the Ottoman clock towers in 2010, their multifunctionality by touching upon their philanthropic and commemorative meaning, too. Yet, he, too, leaves façade clocks aside, arguing that they are beyond the aims of his article. ${ }^{8}$ The same year, Mehmet Bengü Uluengin outlines different trends that played their part in the construction of tower clocks in Anatolia. Interestingly enough, he shows that tower clocks were sometimes considered as modern version of muvakkithanes. In his comment on Uluengin's article and his book on the transformation of Ottoman temporal culture starting from the reign of Selim III (r. 1789-1807), Avner Wishnitzer stresses the coexistence of two different hour systems, that is alla turca (or, Turkish-style) and alla franca (or, European-style), until the Republic, that enriches their explanation of the coexistence of muvakkithanes and tower clocks. ${ }^{9}$ Vanessa Ogle investigates the adoption of mean time in a colonial city of British Empire, Bombay, on one hand and in

4. Salim AYDÜZ, “İstanbul'da Zamanın Nabzını Tutan Mekânlar Muvakkithaneler”, İstanbul, 51 (Ekim 2004), p. 92-97; Salim AYDÜZ, “Osmanlı Devleti’nde Küçük Gözlemevleri ‘Muvakkithaneler”, Güler EREN et al., (eds.), VIII, Osmanll, Ankara, Yeni Türkiye, 1999, pp. 664-675.

5. Server DAYIOĞLU, Osmanlı'da Zamanı Belirleme Mekânları İstanbul Muvakkithaneleri, İstanbul, Kültür A. Ş., 2010.

6. Zeliha KumBASAR, “Osmanlı Dönemi İstanbul Muvakkithaneleri”, Yıldız Teknik Üniversitesi Fen Bilimleri Enstitüsü Mimarlık Tarihi ve Kuramı Programı, Unpublished MA Thesis, İstanbul, 2008.

7. Hakkı ACun, Anadolu Saat Kuleleri, Ankara, Atatürk Kültür Merkezi, 1994.

8. Klaus KreISER, "Ottoman Clock Towers: A Preliminary Survey and Some General Remarks on Construction Dates, Sponsors, Locations and Functions”, Mustafa KAÇAR and Zeynep DuRUKAL (eds.), Essays in honour of Ekemeleddin İhsanoğlu, Vol. 1, İstanbul, IRCICA, 2006, pp. 542-556.

9. Avner Wishnitzer, Reading Clocks, Allaturca Time and Society in the Late Ottoman Empire, Chicago and London, The University of Chicago Press, 2015. 
Beirut, a multicultural commercial hub of the late Ottoman period, on the other. ${ }^{10}$ Ogle points to a gradual adoption of mean time in these two different non-Western centers, and maintains that it was not dissimilar to certain European cities. This article is a contribution to this debate.

\section{Historical Background}

Since the early days of Islam, timekeeping was considered to be of great importance. Essential practices that believers must fulfil, such as daily prayer, hajj, fasting, religious festivals etc. are all subject to timekeeping.

The number and time of daily prayers were not clearly established in the early phase of Islam, although these prayers were mandatory according to the Quran. The exact number of daily prayers was fixed in the eighth century, albeit not their precise times. ${ }^{11}$ Starting from the ninth century, astronomical and mathematical principles were set by Islamic scholars to determine daily prayer times according to the position of the Sun and the Earth. These principles required precise measurements. Accordingly, Islamic scholars improved astronomical and mathematical knowledge they had inherited from Greek scholars, along with the instruments used for time measurement, namely sundials, water clocks, etc. In the very beginning of the ninth century, in 801, Abbasid caliph Harun al-Rashid (r. 766-809) sent a water clock made by Muslim technicians to the Roman Emperor Charlemagne (r. 800-814), who was astounded. ${ }^{12}$ Moreover, two of the most famous early Islamic scholars, Habash al Hasib and Thabit ibn Qurra, wrote treatises on sundials in the latter part of the ninth century and the early tenth century. ${ }^{13}$

Prayer times were fixed in the eighth century -according to the prophet's practices and sayings- at five per day: Evening prayer, when the sun disappears over the horizon; nightfall prayer, when the red light is gone from the western sky and there is no scattered light in the sky; morning prayer, when the sky begins to lighten up; noon prayer, when the sun starts to decline after reaching its highest point in the sky; afternoon prayer, when the length of an object's shadow reach the shadow of subject at noon plus its own length.

Since the prayer times are defined according to the position of the Sun that varies throughout the year, these principles require precise astronomical measurements and observations. Whereas noon and afternoon prayers' time can be measured using a sundial, ${ }^{14}$ the other three need to be determined in a different way, as the shadow of the gnomon during the sunrise and sunset is infinite and there is no shadow after sunset. Indeed, this is where water clocks step in. Having done the required observations and

10. Vanessa OgLe, "Whose Time Is It? The Pluralization of Time and the Global Condition, 1870s1940s”, The American Historical Review, 118/5 (2013), pp. 1376-1402.

11. Stephen P. BLAKE, Time in Early Modern Islam: calendar, ceremony and chronology in the Safavid, Mughal and Ottoman empires, New York, Cambridge University Press, pp. 3-4.

12. Carlo M. CiPOLlA, Clocks and Culture 1300 - 1700, New York, Walker and Company, 1967, pp. 2526.

13. J. L. Berggren, "Sundials in Medieval Islamic Science and Civilization”, The Compendium, 8/2 (June 2001), p. 9.

14. Ibidem, p. 8. 


\section{ÜÇSU Witnesses of the Time}

calculations with the help of various instruments such as astrolabe, quadrant and so on, water clocks were used to determine the time passed from one prayer to another.

In addition, the need for timekeeping led to the establishment of a new institution in the Muslim world, which is muvakkithane (clock room). It appeared for the first time during the Mamluk era in Cairo in the $13^{\text {th }}$ century and became prevalent across the Near East in the 14th century. A muvakkit (time measurer) was officially employed to determine the prayer times. Some incumbents of the post became famous owing to the treatises they wrote on timekeeping as well as on astronomy itself. ${ }^{15}$ Muvakkits tended to use sundials and water clocks and many of them contributed to the development of these instruments. The sundial applied on a horizontal base in the complex of Umayyad Mosque in the latter part of the $12^{\text {th }}$ century is one of the most elaborate ones in the Muslim world. ${ }^{16}$ Water clocks, too, were to develop across the Muslim domains. Al-Djazari's (1136-1206) automated water clocks made in the early $13^{\text {th }}$ century were the summit of its kind in the lands of Islam. ${ }^{17}$ Water clocks became prevalent across the Muslim world by the early $15^{\text {th }}$ century and became the most common instrument used by the muvakkits. ${ }^{18}$

Elsewhere in the world, new developments in timekeeping were taking place, too. A new type of clock was invented toward the end of the 13h century in Europe: the mechanical clock, made possible by the application of the verge-and-foliot escapement. From the late 14th century on, this invention altered the hour system in Europe dramatically. They were installed on public buildings throughout Europe with enthusiasm. Since these mechanisms were not sufficient to show seasonal hours, as they become widespread, daily life started to be organized according to equal hours. ${ }^{19}$ Yet, Muslims appear to had balked at using mechanical clocks at this early period.

\section{Timing Istanbul}

The Ottoman Empire, that emerged east of the Sea of Marmara in the first years of $14^{\text {th }}$ century, inherited the knowledge regarding timekeeping previously produced in the Muslim world. In addition, as the Ottomans almost immediately began to expand towards Europe, they got in contact with the knowledge produced in the West.

We have little information on timekeeping activities and muvakkithanes during the early period of the Ottoman sultanate until the conquest of Constantinople by

15. David A. KING, "Mamluk astronomy and the institution of the muwaqqit", in Islamic Astronomy and Geography, Ashgate Surrey and Burlington, 2012, V, pp. 153-162.; Salim AYDÜZ, "Muvakkithane”, Türkiye Diyanet Vakfi Íslam Ansiklopedisi, 31, (2006), pp. 413-415.

16. David A. KING, “Astronomy and Islamic Society: Qibla, gnomonics and timekeeping”, in Roshdi RASHED (ed.), Enclyclopedia of the History of Arabic Science, London and Newyork, Routledge, Vol.1, pp. 165-166.

17. D. R. HILl, “al-Djazari” P. Bearman, et al. (eds.), Encyclopaedia of Islam, second edition, <http://dx.doi.org.proxy.lib.umich.edu/10.1163/1573-3912_islam_SIM_8506> (consulted 11-11-2017).

18. BLAKE, Time in Early Modern Islam, p.6.

19. Gerhard DoHRn-VAn Rossum, History of the Hour, Chicago and London, The University of Chicago Press, 1996, pp. 45-172. 
Mehmed II (r. 1451-1481). ${ }^{20}$ However, one might infer that the Ottomans would have produced or at least used knowledge concerning timekeeping and constructed muvakkithane(s). Right after the conquest of Constantinople, Mehmed II ordered the construction of a complex of buildings, named after him and completed in 1470, consisting of a mosque, madrasas and a muvakkithane. This muvakkithane is, according to what we know, the first and the oldest of Istanbul. ${ }^{21}$ Moreover, sundials were drawn on the Southwestern wall of the Western minaret of the mosque. ${ }^{22}$ Mehmed II also ordered to build a horizontal sundial, applied on a standing base, which is in the courtyard of Topkap1 Palace today. ${ }^{23}$

One of the essential contributions of the Ottomans to timekeeping is the creation of a post at the Court called müneccimbaşs or head astrologer. Even though the term müneccim (astrologer) refers to people whose principal occupation is making predictions about future events, in the Ottoman context they were also charged with preparing calendars and imsakiye (Ramadan timetable), besides determining auspicious and inauspicious days for planned activities and campaigns. Furthermore, they were responsible for the appointment of muvakkits. ${ }^{24}$

By the time Constantinople was conquered, the population of the city had decreased significantly. ${ }^{25}$ Mehmed II tried to remedy that, ordering massive reconstruction works aimed at reinvigorating the city as the centre of the new empire. Therefore, construction of a muvakkithane as a part of Fatih Mosque complex intended to tell dwellers of Constantinople its new rulers time, which is seasonal and based on daily prayers. His successors carried on in this effort. Mehmed's son Bayezid II (r. 1481-1512) had a complex built in 1506 to which, most likely, a muvakkithane was attached. Famous Ottoman traveler Evliya Çelebi (1611-1682) mentions that this clock room was the one that had the best reputation among Muslims and European sailors. Then, Bayezid II's grandson Suleyman I (r. 1520-1566) got built a complex completed in 1527/8 in the name of his father Selim I (r. 1512-1520) and it included a muvakkithane as well. ${ }^{26}$ Besides, there was another muvakkithane in the complex that Suleyman I got built in his name in 1558. We may observe that the first muvakkithanes were included in the complexes built by the sultans themselves. Even though highranking servants (government officials) of these sultans had similar complexes built in

20. In the first decades of the 15th century Ahmed-i Dai, a scholar who worked under the patronage of Ottoman sultans, translated the famous treatise of Nasir al-Din al-Tusi, called Si Fasl der Ma'rifat- $l$ Takvim (Thirty Chapters on the Knowledge of Calendar) into Turkish. Günay KuT, “Ahmed-i Dai”, Türkiye Diyanet Vakfi Islam Ansiklopedisi, vol. 2, pp. 56-58. Besides, there was a sundial in a mosque in Konya in the early 15th century. See Nusret ÇAM, Osmanll Güneş Saatleri, Ankara, T.C. Kültür Bakanlığı Yayınları, 1990, p. 9.

21. AYDÜZ, “Muvakkithane”, pp. 413-415.

22. ÇAM, Osmanlı Güneş Saatleri, pp.47-49.

23. Ibidem, pp. 107-112.

24. Salim AydüZ, “Osmanlı Devleti’nde Müneccimbaşılık”, Feza GÜNERGUN (ed.), Osmanlı Bilimi Araştırmaları, İstanbul, İstanbul Üniversitesi Yayınları, n. 3.911, 1995, pp. 163-166.

25. Yunus Koç, “Osmanlı Dönemi Nüfus Tarihi”, Türkiye Araştırmaları Literatür Dergisi, 8/16 (2010), p. 195.

26. Salim AYDÜZ, “İstanbul'da Zamanın Nabzını Tutan Mekânlar Muvakkithaneler”, İstanbul, 51 (Ekim 2004), pp. 92-97. 


\section{ÜÇSU Witnesses of the Time}

their name, endowing a muvakkithane apparently remained a privilege of the sultans and of the members of their families until the late $18^{\text {th }}$ century. ${ }^{27}$ This reflects the centralization project of Mehmed II, which aimed to restrict the influence of aristocratic families that had played an important role during the emergence of the Empire, by forcing them to emigrate to the Balkans and establish their pious foundations there. ${ }^{28}$

\section{Muvakkithane Boom}

In the early period of Islam, the hour system was based on the seasonal hours. According to this system, the day and the night were, separately, divided into twelve hours. The night started following the sunset and lasted until the sunrise and the day lasted from the sunrise to the sunset. Therefore, each hour either at night or during the day, understandably, had a different length depending on the season. For instance, on the 41st parallel north, where Istanbul is found, a day hour in the summer solstice happens to be 1 hour 21' 38' and a night hour is 38' 17', ${ }^{29}$ The Ottoman Empire, undoubtedly, inherited this hour system just as they inherited timekeeping knowledge and practices produced by their predecessors. Since the very beginning, this system regulated everyday life, administrative practices, education as well as aforementioned prayer times.

Despite the fact that the seasonal hour system remained in use until the $20^{\text {th }}$ century, Ottoman scholars also developed another time system in the meantime. This system relies on equal hours and divides the day, which starts right after the sunset, into two sets of twelve equal hours. The Ottomans called this system gurubi saat (the hour based on sunset) and in the late $19^{\text {th }}$ century also alla turca saat (Turkish-style hour). According to the evidence, this system was in use among the muvakkits in several regions of the Empire already in the $15^{\text {th }}$ century. They used it to determine the prayer times and the fast times. As Avner Wishnitzer stated, the development of the alla turca system may have been related to the spread of mechanical clocks, for the measurement of the beginning of each day calls for a precision that only mechanical clocks could have. ${ }^{30}$ Indeed, the Ottomans became acquainted with mechanical clocks during the reign of Mehmed II. ${ }^{31}$ However, early mechanical clocks were far away from providing the desired precision for measuring the time according to the strict rules of Islamic religious practice. ${ }^{32}$ The endeavour of Tâqi al-Dîn (1525-1585), former müneccimbaşı

27. Mother of Murat III, Nurbanu Valide Sultan, endowed a muvakkithane within the complex she got built in 1579. See Salim AYDÜZ and Zeliha KUMBASAR, "Üsküdar Semtinde Bulunan Muvakkithaneler ve Güneş Saatleri”, Coşkun YılmAZ (ed.), Uluslar arası Üsküdar Sempozyumu V, İstanbul, 2008, vol. 1, p. 62.

28. Suraiya FAROQHI, Subjects of the Sultans, London and New York, I.B.Tauris, 2000.

29. Ahmet Ziya AKBUluT et al. (eds-., Güneş Saatleri Yapım Kılavuzu, İstanbul, Biryıl Kültür Sanat Ltd., 2010, p. 28.

30. WISHNITZER, Reading Clocks, p. 32.

31. Otto KuRz, Sultan İçin Bir Saat Yakındoğu'da Avrupa Saat ve Saatçileri, İstanbul, Kitap Yayınevi, 2005, p. 27. For English edition see Otto KuRZ, European Clocks and Watches in the Near East, Leiden, Brill, 1975.

32. CIPOLLA, Clocks and Culture, p. 59, see graphic. 
and the founder of the Istanbul Observatory in 1580, to construct a precise mechanical clock for observational purposes ${ }^{33}$ should also be assessed in this context.

Towards the late 18th century, the use of alla turca hour spread through the inhabitants of Istanbul, apart from muvakkits and astronomers. ${ }^{34}$ The progress in the precision of mechanical clocks, the reforms initiated in the early 1770s to establish new military engineering schools in Istanbul and the spread of mechanical clocks across the country probably contributed to this trend. ${ }^{35}$ The reforms initiated in the early 1770s, first focused on introducing new military training and technologies with the aim of enhancing Ottoman military power, but the scope of systematic reforms and transformations expanded to the bureaucracy, education and daily life throughout the $19^{\text {th }}$ century and continued until the end of Empire in the first quarter of $20^{\text {th }}$ century. In the mid- $19^{\text {th }}$ century, a different type of equal hour system came to life as well. ${ }^{36}$

The spread of alla turca hour went hand-in-hand with the rising number of muvakkithanes and of the owners of mechanical clocks. As abovementioned, until the $17^{\text {th }}$ century only five muvakkithanes were built in Istanbul either by sultans or by their family members. In the $17^{\text {th }}$ century, however, a new aristocracy of high-ranking government officials started to emerge, constituting households similar to the Sultan's. ${ }^{37}$ This new class had an important role in the construction of new muvakkithanes. Towards the end of the $18^{\text {th }}$ century, Laleli Mosque complex, completed in 1763, included a muvakkithane. ${ }^{38}$ Another one was attached to Koca Mustafa Pasha complex, built around a mosque converted from a church in 1486, by the endowment of Shaykh al-Islam Veliyüddin Efendi (d. 1768) ${ }^{39}$ probably after being appointed the head of ulama in 1760. Moreover, Mustafa III (r. 1757-1774) had a mosque built, called Ayazma Mosque, in the name of his mother and brother in 1760 , to which a

33. Sevim TEKELI, 16'ncı Asırda Osmanlılar'da Saat ve Takiyüddin'in “Mekanik Saat Konstrüksiyonuna Dair En Parlak Yıldızlar" Adlı Eseri, Ankara, T.C. Kültür Bakanlığı Yayınları, 2002, p. 43; David A. KING, "Taḳi al-Dīn", Encyclopaedia of Islam, Second Edition (eds.) <http://dx.doi.org/10.1163/15733912_islam_SIM_7337> (consulted 16-11-2017)

34. WISHNITZER, Reading Clocks, p.33.

35. Mustafa KAÇAR, “Tersâne Hendesehânesi'nden Bahriye Mektebi'ne Mühendishâne-i Bahrî-i Hümâyûn”, Osmanlı Bilimi Araştırmaları, 9/1-2 (2008), p. 71; CIPOLLA, Clocks and Culture, p. 59, see graphic.

36. Ekmeleddin İHSANOĞLU and Feza GÜNERGUN, "Osmanlı Türkiyesinde "Alaturka Saat”ten "Alafranga Saat”e Geçiş”, X. Ulusal Astronomi Kongresi, İstanbul, 1996, pp. 436-437.

37. Jane Hathaway, "Households in the Administration of the Ottoman Empire", Türklük Bilgisi Araştırmaları, 40, (december 2013), pp. 127-149; Jane HATHAWAY, "Household", Encyclopaedia of Islam, three, <http://dx.doi.org.proxy.lib.umich.edu/10.1163/1573-3912_ei3_COM_30525> (consulted 22-1-2018)

38. Gülsün TANYELI, "Laleli Külliyesi”, Dünden Bugüne İstanbul Ansiklopedisi, , İstanbul, Tarih Vakfi Yurt Yayınları, 1994, vol. 5, pp. 190-192. The muvakkit of this mosque, Çınarizade İsmail Efendi translated Domenique Cassini's book Tables de Astronomique, into Turkish in 1765, under the title of Tercüme-i Zic-i Kasini (Şeref ETKER, "Salih Murat Uzdilek ve 'Logoritmanın Türkiye’ye Girişi’”, Osmanlı Bilimi Araştırmalarl, 8/2 (2007), pp. 62-63 and the note 24).

39. Nazif VeliKÂHYAOĞLU, Sümbüliyye Tarikatı ve Kocamustafapaşa Külliyesi, İstanbul, Çağr1 Yayınları, 2000, p. 155; Tahsin ÖzCAN, "Veliyüddin Efendi”, Türkiye Diyanet Vakfi İslam Ansiklopedisi, vol. 43, pp. 40-42. 


\section{ÜÇSU Witnesses of the Time}

muvakkithane was attached, too. ${ }^{40}$ In addition, during the reconstruction of the Eyup Sultan Mosque following the order of Selim III (r. 1789-1807), a muvakkithane was attached to the complex in $1800 .^{41}$ From this period on, muvakkits started to fix broken mechanical clocks that belonged to local inhabitants. ${ }^{42}$ This period also witnessed the first attempts at regulating the official working hours. ${ }^{43}$

The first years of the $19^{\text {th }}$ century witnessed further reform endeavours. Selim III established a new army called Nizam- $\iota$ Cedid (New Order), which cost him his reign in 1807. A year later, Mahmud II (r. 1808-1839) ascended to the throne. He was well aware that modern states needed to strengthen central administration. Therefore, he initiated systematic reforms in the army and bureaucracy. Following the abolishment of the Empire's traditional military units, the Janissaries, and the foundation of a new modern army, he implemented reforms in education, bureaucracy and daily life in order to modernise the state itself and even the subjects of the Empire. ${ }^{44} \mathrm{~A}$ fair amount of decrees considering the time discipline and regulation were issued within this context. ${ }^{45}$

In 1813 he had a muvakkithane built right next to the New Mosque (Yeni Cami), built in 1665, and this muvakkithane became the principal muvakkithane according to which the official hours were regulated throughout the $19^{\text {th }}$ century. ${ }^{46}$ Thereafter, he had another muvakkithane built in the memory of his father Abdulhamid I (r. 1773-1789) in 1820, next to Beylerbeyi Mosque, which had been built by his father and which Mahmud renovated. ${ }^{47}$ Additionally, two more mosques built by the endowment of Mahmud II, Nusretiye Mosque (1826) and Tevfikiye Mosque (1832), included muvakkithanes next to them. ${ }^{48}$

Moreover, in 1812, Mahmud II ordered the renovation and refurbishment of the Sufi lodge that had been founded in the first half of the $16^{\text {th }}$ century by a prominent Sufi Yahya Efendi in Beşiktaş. This Sufi group had links to the Ottoman dynasty, which granted it great prestige and led to its expansion throughout the Empire. During

40. Server DAYIOĞLU, Osmanlı'da Zamanı Belirleme Mekânları İstanbul Muvakkithaneleri, İstanbul, Kültür A.Ş., 2010, p. 75.

41. M. Baha TANMAN, “Eyüb Sultan Külliyesi’’, Dünden Bugüne İstanbul Ansiklopedisi, vol. 3, 238-239.

42. AYDÜZ, “İstanbul’da Zamanın Nabzını Tutan Mekânlar Muvakkithaneler”, pp. 93-94.

43. WISHNITZER, Reading Clocks, pp. 45-47.

44. Niyazi BeRKeS, The Development of Secularism in Turkey, Montreal, McGill University Press, 1964, pp. 89-135; J. H. KrAMERS, "Maḥmūd II", Encyclopaedia of Islam, First Edition (1913-1936), <http://dx.doi.org.proxy.lib.umich.edu/10.1163/2214-871X_ei1_SIM_4440> (consulted 20-1-2018)

45. WISHNITZER, Reading Clocks, p. 50.

46. Gülberk BıLECıK, “Gözden Kaçan Bir Kültür Mirasımız: Yeni Cami Muvakkithanesi”, Atatürk Üniversitesi Güzel Sanatlar Fakültesi Dergisi, 10 (2006), p. 44.

47. Süheyl ÜNVER, “Osmanlı Türkleri İlim Tarihinde Muvakkithaneler”, Atatürk Konferanslarl 19711972, Ankara, 1975, p. 235; Tahsin Öz, İstanbul Camileri I-II, Ankara, Türk Tarih Kurumu ,1997, p. 12; Zeliha KumBASAR, "Osmanlı Dönemi İstanbul Muvakkithaneleri”, Yıldız Teknik Üniversitesi Fen Bilimleri Enstitüsü Mimarlık Tarihi ve Kuramı Programı, Unpublished MA Thesis, İstanbul, 2008, p. 50.

48. AYDÜZ, “İstanbul'da Zamanın Nabzını Tutan Mekânlar Muvakkithaneler”, p. 95; DAYIOĞLU, Osmanlı'da Zamanı Belirleme Mekânları, pp. 87-89, 108; Öz, Ístanbul Camileri II, p. 66; Yasemin SunER, “Nusretiye Camii’’, Dünden Bugüne İstanbul Ansiklopedisi, vol. 6, p. 105. 
Mahmud's renovation, new buildings were attached to the lodge. ${ }^{49}$ Its muvakkithane, which does not exist anymore, might have been constructed during the renovation. Another Sufi lodge built at the beginning of the $19^{\text {th }}$ century by Feyzullah Şükrü Efendi (d. 1814), also known as Küçük Efendi, may have included a muvakkithane alongside a fountain endowed by Mahmud II during its reconstruction in 1825 . $^{50}$ Additionally, this sultan ordered in 1836 the restoration of another Sufi lodge, Merkez Efendi complex, founded in the first half of the $16^{\text {th }}$ century ${ }^{51}$, and its muvakkithane may have been built precisely during these $19^{\text {th }}$-century renovation works. Last, the muvakkithane called Tabbye-i Tayyibede was built upon his order in $1838 .^{52}$

The unprecedented number of muvakkithanes built by Mahmud II does, certainly, reflect his intention to promote the generalisation of time management and discipline. However, in addition to the ones he ordered to be built, there are several muvakkithanes that were, most likely, sponsored by other dignitaries of his reign. For instance, Halet Efendi (1760?-1823), an Ottoman bureaucrat and diplomat, had two muvakikthanes built. Halet Efendi had served as the ambassador in Paris from 1803 to 1806. After returning to Istanbul he continued to deal with foreign affairs. However, he was sent to exile to Konya in 1807 for his illegal dealings with Britain. Following the accession of Mahmud II he was pardoned and came back to Istanbul. He soon became the closest person of the sultan. During this period when he was in favour at the Court, Halet Efendi endowed two muvakkithanes. One of them was built in 1818 within the complex of Galata Sufi lodge of which he was a disciple. The other one was built within the Sinan Pasha complex in Beşiktaş, most likely sometime after 1818 and before 1823 when he was exiled, consecutively, to Bursa and Konya. ${ }^{53}$ Given that he was very close to Mahmud II and that he held high posts of the bureaucracy, it is safe to assume that either the Sultan encouraged him to build muvakkithanes or that Halet wanted to show his commitment to his sultan's reform effort.

This reformist sultan was also involved in the construction of clock towers in the Empire's provinces. During his reign at least six clock towers were erected outside Istanbul. ${ }^{54}$ Apparently, he was also interested in the installation of clocks on the façades of buildings and already existent towers in the imperial capital, even though he did not fund the construction of any independent clock tower.

49. M. Baha TANMAN, "Yahya Efendi Külliyesi”, Türkiye Diyanet Vakfi İslam Ansiklopedisi, vol. 43, p. 246; Haşim ŞAHIN, "Yahya Efendi, Beşiktaşl1", Türkiye Diyanet Vakfi İslam Ansiklopedisi, vol. 43, pp. 243-244.

50. M. Baha TANMAN, “Küçük Efendi Külliyesi’’, Dünden Bugüne İstanbul Ansiklopedisi, vol. 5, p. 150; ÜNVER, “Osmanlı Türkleri İlim Tarihinde Muvakkithaneler”, p. 246.

51. M. Baha TAnMAN, “Merkez Efendi Külliyesi’’, Dünden Bugüne Ístanbul Ansiklopedisi, vol. 5, p. 397.

52. ÜNVER, “Osmanlı Türkleri İlim Tarihinde Muvakkithaneler”, p. 252.

53. Abdülkadir ÖzCAN, "Hâlet Efendi”, Türkiye Diyanet Vakfi İslam Ansiklopedisi, vol. 15, pp. 249-251; Necdet SAKAOĞLU, “Halet Efendi” Dünden Bugüne Ístanbul Ansiklopedisi, vol. 3, İstanbul, Tarih Vakf1 Yurt Yayınları, 1994, pp. 498-499; DAYIOĞLU, Osmanlı’da Zamanı Belirleme Mekânlarl, pp. 74-75; ÜNVER, “Osmanlı Türkleri İlim Tarihinde Muvakkithaneler”, p. 237; BAŞBAKANLIK OSMANLI ARŞIVLERI (hereafter BOA), MVL., fold. 350, doc. 41.

54. Klaus Kreiser, “Ottoman Clock Towers: A Preliminary Survey and Some General Remarks on Construction Dates, Sponsors, Locations and Functions”, Mustafa KAÇAR and Zeynep DuRUKAL (eds.), Essays in honour of Ekemeleddin İhsanoğlu, İstanbul, IRCICA, 2006, vol.1, pp. 545-546, 552-555. 


\section{ÜÇSU Witnesses of the Time}

In the first days of 1831, Galata Tower burnt down, and Mahmud II immediately ordered its renovation. He demanded that a clock be installed on the tower as well. Indeed, among the treasures of Istanbul Archeological Museum there is a bell from Galata Tower. ${ }^{55}$ Apart from this, Mahmud seems to have ordered the installation of another clock. In 1832, modern surgery training began in a school founded within the Topkap1 Palace. Yet, soon it became apparent that a bigger place was needed, linked, among other issues to the reforms of the education provided in the school, and the institution was moved in the building of Enderun A ğalar Mektebi (School of Enderun Aghas). Thus, the courses began in the Mekteb-i Tibbiye-i Adliye-i Şahane (Imperial School of Medicine) after the restoration of Enderun A ğalar Mektebi completed in 1838, short after the sultan's death. ${ }^{56}$ According to a document in the Ottoman archives, dated 22 April 1841, this building had a clock tower. ${ }^{57}$

\section{Clock Towers on the Stage}

The first independent clock tower in Istanbul was erected in 1849 by order of Sultan Abdülmecid (r. 1839-1861). This clock tower was located in the courtyard of the Imperial Arsenal in Tophane. The tower was fifteen meters long, and at its top were four clock faces showing the alla turca hour. ${ }^{58}$ Given that the first extensive regulations for time discipline were implemented in the armed forces, the choice of clock tower's location makes a good sense.

Initial endeavours to introduce time discipline during the first half of the $19^{\text {th }}$ century did not work out well. Even though the Court was aware of the need for time management and took action accordingly, the regulations that were adopted had little practical impact. ${ }^{59}$ Istanbul was to wait the second half of the $19^{\text {th }}$ century for the implementation of a more meticulous time discipline among all strata of the society. In the course of Crimean War (1853-1856), the Ottoman army had the opportunity to get closely acquainted with the meantime since the Ottoman military had to coordinate their actions with its allies Britain and France against Russia. ${ }^{60}$ Besides, the establishment of telegraphs lines during this war, construction of railways, launching of ferry transportation and foundation of new schools based on modern institutional and pedagogical practices triggered the spread of time-showing structures, that is to say muvakkithanes, clock towers and façade clocks, across Istanbul.

55. Semavi EYICE, “Galata Kulesi”, Dünden Bugüne Ístanbul Ansiklopedisi, vol. 3, p. 360; Doğan GÜNDÜZ, “Galata Kulesi’ndeki Saatleri Ayarlama Küresi,” Toplumsal Tarih, 126 (Haziran 2004), p. 26.

56. Yeşim Işıl ÜLMAN, “Mekteb-i Tıbbiye-i Şâhâne’de (Galatasaray Tıbbiyesi’nde) Eğitim”, Hüsrev HATEMI and Ayten AltinTAŞ (eds.), Türk Tip Ĕgitiminin Önemli Adımları, İstanbul, CSA Global Publishing, 2006, pp. 71-72; Hasan DOĞRUYOL, "Cerrahlık", Türkiye Diyanet Vakfi Íslam Ansiklopedisi, vol. 7, pp. 421-423.

57. BOA, C.SH, fold. 7, doc. 334.

58. Tarkan OKÇUOĞLU, “Tophane Saat Kulesi,” Dünden Bugüne İstanbul Ansiklopedisi, vol. 7, p. 278.

59. WISHNITZER, Reading Clocks, pp. 73-75.

60. Doğan GÜNDÜZ, “Osmanlı’nın Mekanik Saatle Buluşması,” İstanbul, 51 (Ekim 2004), p. 122. 
During the restoration of the Haghia Sofia in 1853 by Swiss architects Fossati brothers, a muvakkithane was attached in the southern part of it for the first time. ${ }^{61} \mathrm{~A}$ few years later, sultan Abdülmecid's mother Bezmiâlem Valide Sultan (1807-1853) endowed a complex including a muvakkithane near Dolmabahçe Palace, which was built by Abdülmecid in 1855. ${ }^{62}$ In 1857 a benefactor named el-Hacc Hasan Ağa (?-?) endowed a muvakkitane next to the Beykoz Mosque, which had been built around 16261628 by a janissary agha Bostancıbaşı Mustafa Ağa. ${ }^{63}$

In addition to these new muvakkithanes of Istanbul, a mechanical clock was installed, most likely in 1859, in the tower rising from the middle of Bahriye Merkez Hastanesi (Central Naval Hospital), which had been built in 1838 and used at the beginning as Bahriye Mektebi (Naval Academy). ${ }^{64}$ A new campus of the Harbiye Nezareti (Ministry of War) was finished in 1866. On the both sides of the main gate of the campus, there are two towers, shorter than the gate. Two mechanical clocks showing the alla turca hour were installed on both towers, which are still in existence. In 1848, the School of Medicine in Galatasaray was devastated by fire. ${ }^{65}$ Its renovation finished in 1865 and the building was then put at the disposal of various military schools for short terms. Three years later, in 1868, it was sublet to Galatasaray High School. A mechanical clock was emplaced on the façade facing the courtyard.

Christian religious orders and missionary groups became very active in the Ottoman Empire in the mid-nineteenth century, founding several new schools. The schools' schedules were based, needless to say, on meantime. ${ }^{66}$ Foreign schools built in Istanbul during this period tended to place mechanical clocks on their façades. The French schools of Saint Michel, built in 1870, Saint Benoît, that had been founded as a Jesuit college in 1583 and underwent a major expansion in 1879, and Saint Pulcherie, built in 1890, all installed mechanical clocks showing meantime on the façades. Furthermore, the Greek schools Fener High School and Zapyon High School, built in 1880 and 1882 respectively, included mechanical clocks on their façades, too. Lastly, Robert College, founded in 1863 and run by missionaries from the USA, had a new building added in 1892, which displayed a mechanical clock. ${ }^{67}$

61. Semavi EYICE, “Ayasofya Muvakkithanesi”, Dünden Bugüne İstanbul Ansiklopedisi, vol. 1, p. 461; BOA, A \}MKT.NZD., fold. 36, doc. 98.

62. Çelik Gülersoy, "Dolmabahçe Sarayı”, Dünden Bugüne İstanbul Ansiklopedisi, vol. 3, p. 90; DAYIOĞLU, Osmanlı'da Zamanı Belirleme Mekânları, p. 67; Afife BATUR, "Dolmabahçe Camii”, Dünden Bugüne İstanbul Ansiklopedisi, vol. 3, p. 88.

63. Ahmed Nezih GaLiTEKin, Beykoz Kitabeleri, İstanbul, Beykoz Belediyesi, 2008, vol.1, p. 141.

64. Nuran YILDIRIM, “Bahriye Merkez Hastanesi”, Dünden Bugüne İstanbul Ansiklopedisi, vol. 1, pp. 548-549; "Kasımpaşa Deniz Hastanesi Kulesi’ne Ait Saat”, <https://denizmuzesi.dzkk.tsk.tr/tr/content/328> (consulted 10-11-2017)

65. Nuran YILDIRIM, İstanbul'un Sağllk Tarihi, İstanbul, Ajansfa, 2010, pp. 262.263.

66. WiSHNITZER, Reading Clocks, p. 106.

67. İlkur Polat HAYDAROĞLU, Osmanlı Imparatorluğu’nda Yabancı Okullar, Ankra, Kültür Bakanlı̆̆1, 1990, p. 113; “171 Y1llk Tarih” <http://www.sp.k12.tr/turkce/lisemiz/article/170-yillik-tarih-144> (consulted 10-11-2017); Süleyman BüYÜKKARCI, Türkiye'de Rum Okullarl, Konya, Yelken Basım Yayım Dağıtım, 2003, pp. 115-116, 159-160; Sula BozIS, “Fener Rum Erkek Lisesi”, Dünden Bugüne Ístanbul Ansiklopedisi, vol. 3, p. 283; Recep ÜLKE, İstanbul Amerikan Kolejinin Tarihçesi, İstanbul, Yeni Matbaa, 1956, p.17. 


\section{ÜÇSU Witnesses of the Time}

The reign of Abdülhamid II (r. 1876-1909) witnessed the construction of new muvakkithanes as well as the erection of new clock towers and installation of façade clocks. This boom of time-displaying constructions owed to the fact that new public facilities and infrastructures (such as tramways, steamship lines, schools and post offices) proliferated; these were based on stricter time regulations and required that the city-dwellers be informed widely about the exact time. ${ }^{68}$ Moreover, the participation of the Ottoman Empire in the Meridian Conference organised in Washington in 1884 to determine a base meridian for the standardisation of time, stimulated the appearance of clocks showing meantime on the towers and buildings sponsored by the Ottoman court. $^{69}$

In the same year just before the Meridian Conference, the Interior Ministry issued a decree suggesting that two mechanical clocks showing the meantime be emplaced in order to ease affairs (teshîl-i muamelât), one on the historical peninsula, where Topkap1 Palace and administrative centre of the Empire located, and one in Tophane district. ${ }^{70}$ In response to the decree, the institutions concerned expressed their opinions as to where and how these clocks could be installed. Two different opinions emerged in the end. One recommended that one of them be installed on one of the towers of Ministry of War, built in 1866, and the other be installed on Tophane clock tower. Second opinion suggested that two new clock towers, one in Sultanahmet Square and one in Beşiktaş Square, be built. However, as the construction of new towers would have cost too much money, the first opinion prevailed. This decision of replacing one of the clocks with new ones showing meantime is compatible with the declaration of the Ottoman representatives at the Meridian Conference indicating that alla turca hour and the meantime would coexist in the country. ${ }^{71}$

Later on, Abdülhamid II ordered a clock tower to be built right next to the Yildiz Palace, where he lived and governed. The tower completed in 1890 was paid from the sultan's private treasury. ${ }^{72}$ In the same year, Sirkeci train station opened with two clock towers next to its crown gate. Four mechanical clocks were installed on these two towers. $^{73}$

In 1892, a new building of Istanbul Post Office was built in Eminönü, of which the gate faces the port, the ferry pier and the tram lines. A few months later, a request was made that two mechanical clocks showing alla turca hour and meantime be attached over its gate so that everybody could learn the time. ${ }^{74}$ Abdülhamid II

68. WISHNITZER, Reading Clocks, p. 148.

69. Ibidem, p. 151.

70. BOA, İ.DH., fold. 940, doc. 74403.

71. WishniTZER, Reading Clocks, p. 151. For the proceeding of the conference see International Conference Held at Washington for the Purpose of Fixing a Prime Meridian and a Universal Day, Washington D.C., Gibson Bros., 1884; and for the declaration of the Ottoman delegation, pp. 178-179.

72. Kemal ÖzDEMIR, Osmanlı’dan Günümüze Saatler, İstanbul, Creative Yayınc1lık, 1993, p. 206.

73. Yıldız SALMAN “'Sirkeci Garı”, Dünden Bugüne İstanbul Ansiklopedisi, vol. 7, p. 13.

74. BOA, Y.PRK.PT., fold. 8, doc. 111; Nurcan YAZICI, "Teshîl-i Muâmelât İçin Saat: II. Abdülhamid Dönemi'nde İstanbul'da Yapılması Düşünülen Saat Kulesi Yapım Etkinlikleri”, Ahmet GÜRBÜZ (ed.), Safranbolu Saat Kulesi ve Zaman Ölçerler Sempozyumu, Safranbolu, Karabük Valiliği Kültür Hizmeti, 2011, p. 114. 
sponsored another clock tower in 1894, which is located in Dolmabahçe between the main gate of Dolmabahçe Palace and Bezmialem Valide Sultan Mosque, facing the muvakkithane of the mosque. ${ }^{75}$

In the meantime, new muvakkithanes continued to be built in different parts of the city. Muvakkithane of Hubyar Mosque (1889), of Bala complex (1891-2), of Teşvikiye (1894) and Atik Ali Mosque are some of them. For the full list of extant and disappeared muvakkithanes see Table 1 and Table 2, at the end of the article.

Clock tower construction caused several controversies. In 1886, the Armenian community of Surp Kevork Church asked for permission to build a clock tower on the church during the reconstruction project. The government, however, refused to grant it, fearing that bells would be installed bells on it, which could spark conflict with local Muslim dwellers. Next year, the authorities changed their decision and let the community build the tower. As it turns out, the government's nightmare soon came true, and the city council had to order the community to remove the bell they had installed in the tower. ${ }^{76}$

Touraj Atabaki showed how striking clocks caused public indignation and how this phenomenon made some scholars interpret the erection of clock towers in terms of secularisation or Westernisation. ${ }^{77}$ It is true that the Ottoman government's wariness of bells would seem logical with regards to preventing inter-religious conflicts, as bells are indeed a crucial part of ecclesiastic rituals. However, this obsession against new bells was not, apparently, limited to churches. Merchants and artisans of Kumkap1 neighbourhood petitioned the city council for a license to build a two-and a-half-meterslong clock tower in their neighbourhood, to commemorate the 25th anniversary of Abdülhamid II's enthronement in 1900. They volunteered to collect the money. Although the government granted the permission to build this relatively short tower, an annotation stated that this permission should not be exploited. ${ }^{78}$ This annotation most probably refers to a possible outcry caused by the installation of a bell.

In the turn of $20^{\text {th }}$ century, new building of the Great School of Medicine (Mekteb-i Tibbiye-i Şahane) was finished. The opening ceremony took place on the 13 September 1903, whereas the construction had concluded in 1900, according to an inscription on the building. Two clock towers were located on both sides of the main gate where two mechanical clocks were installed showing the meantime and alla turca hour. ${ }^{79}$ A couple of years later, Abdülhamid II order the construction of a new clock tower as well as a mosque within the complex of the hospital that he had built in 1899 in the name of his daughter Hatice who died in her infancy. The building was finished in 1907 and the tower included clocks that showed alla turca hour and the meantime.

75. Hakk1 ACuN, “İstanbul’un Saat Kuleleri”, İstanbul, 51 (Ekim 2004), p. 103.

76. Pars TuĞLACI, İstanbul Ermeni Kiliseleri, İstanbul, Pars Yayın Ltd. Şti., 1991, p. 160; BOA, DH.MKT., fold. 1384, doc. 112; BOA, DH.MKT., fold. 1703, doc. 112.

77. Touraj ATABAKI, "Time, Labour-Discipline and Modernization in Turkey and Iran: Some Comparative Remarks”, Touraj ATABAKI (ed.), The State and The Subaltern: Modernization, Society and the State in Turkey and Iran, London and New York, I.B.Tauris, 2007, pp. 4-5.

78. BOA, Y.PRK.ŞH., fold. 11, doc. 36.

79. Afife BAtur, "Mekteb-i Tıbbiyei Şâhâne Binası", Dünden Bugüne İstanbul Ansiklopedisi, vol.5, İstanbul, Tarih Vakfi Yurt Yayınları, 1994, pp. 378-379. 


\section{ÜÇSU Witnesses of the Time}

The last public building with a façade clock built during the reign of Abdülhamid II is probably the Hayrdapaşa Train Station, completed in $1908 .{ }^{80}$

Finally, the last clock tower of the Ottoman Istanbul was erected in Büyükada (Prinkipo), one of the Princes' Islands in 1918, funded by a private company. This tower is still located on the square right across the pier. ${ }^{81}$ For the full list of clock towers and façade clocks see Table 3, in the final Appendix.

\section{Conclusions}

The research outlined here suggests that the power relations within the Ottoman Court reflected upon the organisation of time and space. In accordance with the centralisation project of Mehmed II, endowing muvakkithanes in Istanbul remained an exclusive privilege of the Ottoman dynasty until the $17^{\text {th }}$ century. Rising number of muvakkithanes in the $18^{\text {th }}$ century was grounded in the ambition of newly emerging aristocrats to display and promote the power of their households. The reign of Mahmud II disrupted this phenomenon. His reforms aimed at recentralising power. This attitude is reflected in his muvakkithane-building activities: great majority of the muvakkithanes built during his reign were constructed upon his order and endowment. Only his righthand man, Halet Efendi, could afford to endow two muvakkithanes, owing to his intimacy with the Sultan.

Until the late $18^{\text {th }}$ century, only scholars used alla turca hour system in order to determine prayer times across the country. As mechanical clocks progressed and became prevalent amongst the subjects of country, the use of alla turca hour began to spread. Moreover, it became essential to inform the city-dwellers about time, so they could arrange their daily errands and duties, regulated according to the alla turca hour. Sultans and bureaucratic elite of the Empire took action in this period and funded new time-indicating constructions across the city.

As I have argued, during the second half of the $19^{\text {th }}$ century, many clock towers and façade clocks were installed to cater to the changes in daily life, to the newly established public transport facilities, to the new schools, to the reorganised institutions, etc. Therefore, Istanbul was furnished with big clocks, sometimes installed in order to show the sultan's power (Yildız and Dolmabahçe clock towers), sometimes with the intent to make urban life easier, as was the case of the façade clock of the Post Office and the clocks on the train stations. In other cases, the aim was to impose time discipline: the clock towers of the Ministry of War and of the Great School of Medicine served mainly this purpose. Same period witnessed a new wave of muvakkithane boom too. During the last third of $19^{\text {th }}$ century at least ten muvakkithanes were built across Istanbul. On the whole, muvakkithanes and clock towers and façade clocks coexisted

80. Afife BATUR, “Etfal Hastanesi Saat Kulesi ve Mescidi”, Dünden Bugüne Ístanbul Ansiklopedisi, vol. 3, pp. 221-222; Faruk İLKER, Şişli Çocuk Hastanesi Tarihi, İstanbul, (n. e.), 1976, pp. 6-10, 84-85; Y1ldız SAlmAN, “Haydarpaşa Garı”, Dünden Bugüne İstanbul Ansiklopedisi, vol. 4, İstanbul, Tarih Vakfı Yurt Yayınlar1, 1994, p. 30.

81. Yıldızay Zorer, Tarihi Gelişim Sürecinde Büyükada Meydanları, İstanbul, Büyükada Kültür Derneği Yayınları, 2005, pp. 30-32. 
DOSSIER The time of the changes: the last decades of the Ottoman Empire

until the fall of the Ottoman Empire, under the condition that the clock towers were not taller than minarets. ${ }^{82}$

82. Mehmet Bengü Uluengin, "Secularizing Anatolia Tick by Tick: Clock Towers in the Ottoman Empire and the Turkish Republic”, International Journal of Middle East Studies, 42/1 (Feb. 2010), pp. 22-24. 


\section{ÜÇSU Witnesses of the Time}

\section{Appendix}

Table 1: Extant muvakkithanes of Istanbul

\begin{tabular}{|c|c|c|c|}
\hline$\#$ & NAME & DATE & DONOR \\
\hline 1 & Atik Valide Mosque & 1579 & Nurbanu Sultan \\
\hline 2 & Cerrahpaşa Mosque $^{83}$ & ? & 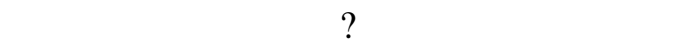 \\
\hline 3 & Sultan Ahmet Mosque & ? & ? \\
\hline 4 & Yeni Valide Mosque & 1710 & Ahmed III \\
\hline 5 & Kocamustafapaşa Mosque & 1760- & Veliyüddin Efendi \\
\hline 6 & Laleli Mosque & 1763 & Mustafa III \\
\hline 7 & Eyüp Mosque & 1800 & Selim III \\
\hline 8 & Selimiye Mosque & 1805 & Selim III \\
\hline 9 & New (Yeni) Mosque & 1813 & Mahmud II \\
\hline 10 & Galata Sufi Lodge & 1818 & Halet Efendi \\
\hline 11 & Beylerbeyi Mosque & 1820 & Mahmud II \\
\hline 12 & Nusretiye Mosque & 1827 & Mahmud II \\
\hline 13 & Arnavutköy Mosque & 1832 & Mahmud II \\
\hline 14 & Tomb of Mahmud II & 1840 & ? \\
\hline 15 & Emirgan Mosque & 1844 & Ağa Hüseyin Pasha ${ }^{84}$ \\
\hline 16 & Yenikapı Sufi Lodge & 1848 & Abdurrahman Nafiz Pasha ${ }^{85}$ \\
\hline 17 & İskender Pasha Mosque & 1851 & Sadık Rifat Pasha ${ }^{86}$ \\
\hline 18 & Ayasofya & 1853 & ? \\
\hline 19 & Dolmabahçe Mosque & 1855 & Bezmiâlem Valide Sultan and Abdülmecid \\
\hline 20 & Beykoz Mosque & 1857 & El-Hac Hasan Ağa ${ }^{87}$ \\
\hline 21 & Güzelce Kasım Paşa Mosque & 1870 & ? \\
\hline 22 & Murad V & 1876 & Murad V 88 \\
\hline 23 & Bala Lodge & $1891 / 2$ & \\
\hline 24 & Teşvikiye Mosque & 1892 & Abdülhamid II $^{89}$ \\
\hline 25 & Atik Ali Mosque & 1899 & \\
\hline 26 & Suadiye Mosque & 1908 & Ahmed Reşad Pasha and Said Bey ${ }^{90}$ \\
\hline 27 & Şehzade Mosque & Late $18^{\text {th }}$ & ? \\
\hline
\end{tabular}

83 ÜNVER list this one amongst the disappeared ones. However, Ahmet Vefa ÇOBANOĞLU states that it still exists and was renovated shortly before 1994 ("Cerrah Mehmed Paşa Külliyesi”, Dünden Bugüne Istanbul Ansiklopedisi, Vol.2, İstanbul, Tarih Vakfi Yurt Yayınları, 1994, p. 413).

84 BOA İ.DH., fold. 340, doc. 22378. Ağa Hüseyin Paşa (1776-1849) was a member of military elite who served as a vizier.

85. ÜNVER, "Osmanlı Türkleri İlim Tarihinde Muvakkithaneler", pp. 231-232. Abdurrahman Nafiz Pasha (d. 1853) was the first finance minister of the Empire.

86. Abdurrahman Cabir VADA, Boğaziçi Konuşuyor ve Kanlıca Tarihçesi, İstanbul, Kitabevi, 2004, p. 69. Sadık Rifat Pasha (1807-1857) served as finance minister and minister of foreign affairs.

87. GaliteKin, Beykoz Kitabeleri, p. 141.

88. Ömer Faruk ŞERIFOĞLU, Su Güzeli: İstanbul Sebilleri, İstanbul, İstanbul Büyükşehir Belediyesi Kültür İşleri Daire Başkanlığı Yayınları, n. 22, 1995, p. 84.

89. BOA, Y.PRK.ASK., fold. 27, doc. 54.

90. Hakan ARLI, “Suadiye Camii”, Dünden Bugüne İstanbul Ansiklopedisi, vol. 7, p. 50. 


\begin{tabular}{l|lcl|}
\hline 28 & Ramazan Efendi Mosque & Late $18^{\text {th }}$ & $?$ \\
29 & Osman Ağa Mosque & 1878 ? & $?$ \\
30 & Mihrişah Valide Sultan Mosque & Late $19^{\text {th }}$ & $?$ \\
31 & Nişancı Mehmed Paşa Mosque & $19^{\text {th }}$ ? & $?$ \\
32 & Kadıköy Pier Mosque & $?$ & $?$ \\
\cline { 2 - 4 }
\end{tabular}

Table 2: Disappeared muvakkithanes of Istanbul

\begin{tabular}{|c|c|c|c|}
\hline \# & NAME & DATE & DONOR \\
\hline 1 & Fatih Mosque & 1470 & Mehmed II \\
\hline 2 & Bayezid Mosque & 1506 & Bayezid II \\
\hline 3 & Yavuz Selim Mosque & $1527 / 8$ & Suleyman I \\
\hline 4 & Süleymaniye Mosque & 1558 & Suleyman I \\
\hline 5 & Anadolu Hisarı Mosque & $1883 ?$ & Abdülhamid II? ${ }^{91}$ \\
\hline 6 & Firuz Ağa Mosque & $?$ & ? \\
\hline 7 & Arap Mosque & ? & $?$ \\
\hline 8 & Çakır Ağa Mosque & ? & $?$ \\
\hline 9 & Çivizade Kızı Mosque & ? & $?$ \\
\hline 10 & Sokollu Mehmed Pasha Mosque & ? & ? \\
\hline 11 & Kılıç Ali Pasha Mosque & ? & $?$ \\
\hline 12 & Molla Çelebi Mosque & ? & $?$ \\
\hline 13 & Bayrampaşa Mosque & ? & ? \\
\hline 14 & Çinili Mosque & & \\
\hline 15 & Kemankeş Mustafa Pasha Mosque & ? & ? \\
\hline 16 & Mihrimah Sultan Mosque & ? & ? \\
\hline 17 & Katip Mustafa Efendi Mosque & ? & ? \\
\hline 18 & Ahmediye Mosque & ? & ? \\
\hline 19 & Hekim Oğlu Ali Pasha Mosque & ? & $?$ \\
\hline 20 & Kandilli Mosque & ? & ? \\
\hline 21 & Nuruosmaniye Mosque & ? & ? \\
\hline 22 & Ayazma Mosque & 1760 & Mustafa III \\
\hline 23 & Şeb Safa Mosque & $?$ & ? \\
\hline 24 & Yahya Efendi Lodge & $1812 ?$ & Mahmud II? \\
\hline 25 & Beşiktaş & Between 1818- & Halet Efendi \\
\hline 26 & Küçük Efendi Lodge & $1825 ?$ & Mahmud II? \\
\hline 27 & Galata Yeni Mosque & $1821 ?$ & Mahmud II ${ }^{92}$ \\
\hline 28 & Kuruçeşme Mosque & $?$ & ? \\
\hline 29 & Merkez Efendi Lodge & $1837 ?$ & Mahmud II? \\
\hline 30 & Tabye-i Tayyibe Mosque & 1838 & Mahmud II \\
\hline 31 & Altunizade Mosque & 1865 & İsmail Zühdi Pasha ${ }^{93}$ \\
\hline
\end{tabular}

91. This mosque was first built during the reign of Mehmed II. However, it was rebuilt by Abdülhamid II in 1883. Its muvakkithane might have been built during this reconstruction project. Tarkan OKÇUOĞLU, "Anadoluhisarı Camii," Dünden Bugüne İstanbul Ansiklopedisi, vol. 1, İstanbul, Tarih Vakfı Yurt Yayınlar1, 1994, pp. 258-259.

92. This mosque acquired its current outlook after the renovation conducted in 1821 during the reign of Mahmud II. Its muvakkithane must have been added then. See Muzaffer ÖZGÜLEŞ, The Women Built the Ottoman World, London and New York, I.B. Tauris, 2017, p. 122. 


\section{ÜÇSU Witnesses of the Time}

\begin{tabular}{|l|lcc|}
\hline 32 & Pertevniyal Valide Sultan Mosque & 1871 & Pertevniyal Valide Sultan \\
33 & Hubyar Mosque & $1889 ?$ & $?$ \\
34 & Cihangir Mosque & $1899 ?$ & Abdülhamid II? ${ }^{95}$ \\
35 & Rumeli Hisar1 Mosque & $?$ & $?$ \\
36 & Yeralt1 Mosque & $?$ & $?$ \\
37 & Nüzhetiye Mosque & $?$ & $?$
\end{tabular}

Table 3: Extant Clock Towers and Façade Clocks of Istanbul erected during the Ottoman Era ${ }^{96}$

\begin{tabular}{|c|c|c|c|c|c|}
\hline N\# & NAME & DATE & DONOR & TYPE & FUNCTIONS? \\
\hline 1 & Tophane Clock Tower & 1849 & Abdülmecid & Tower & No \\
\hline 2 & Naval Academy & 1859 & & Tower & No \\
\hline 3 & Galatasaray High School & 1865 & & Façade & Yes \\
\hline 4 & Ministry of War & 1866 & & Tower & Yes \\
\hline 5 & Lycée Saint Michel & 1870 & & Façade & No \\
\hline 6 & Çiçek Passage & 1876 & & Façade & No \\
\hline 7 & Lycée Saint Benoît & 1879 & & Façade & No \\
\hline 8 & $\begin{array}{l}\text { Fener Greek High } \\
\text { School }\end{array}$ & 1880 & & Façade & No \\
\hline 9 & $\begin{array}{l}\text { Zapyon Greek High } \\
\text { School }\end{array}$ & 1882 & & Façade & No \\
\hline 10 & Beyoğlu City Hall & 1883 & & Façade & Yes \\
\hline 11 & Yildiz Clock Tower & 1890 & Abdülhamid II & Tower & Yes \\
\hline 12 & Sirkeci Train Station & 1890 & & Façade & No \\
\hline 13 & Post Office Building & $1892 / 3$ & & Façade & No \\
\hline 14 & Robert College & 1892 & & Façade & Yes \\
\hline 15 & $\begin{array}{l}\text { Dolmabahçe Clock } \\
\text { Tower }\end{array}$ & 1894 & Abdülhamid II & Tower & Yes \\
\hline 16 & Şişli Children's Hospital & 1907 & Abdülhamid II & Tower & No \\
\hline 17 & $\begin{array}{l}\text { Haydarpaşa Train } \\
\text { Station }\end{array}$ & 1908 & & Façade & No \\
\hline 18 & Büyükada Clock Tower & 1918 & $\begin{array}{l}\text { Antoine Sagredo } \\
\text { (Company) }\end{array}$ & Tower & Yes \\
\hline
\end{tabular}

93. İsmail Zühdi Pasha (1806-1888) was an architect and vizier. See Hakan ARLI, “Altunizade Külliyesi”, Dünden Bugüne İstanbul Ansiklopedisi, vol.1, pp. 230-231.

94. Pertevniyal Valide Sultan (1812-1883) was consort of Mahmud II and mother of Abdülaziz (r. 18611876). See Afife BATUR, “Valide Camii”, Dünden Bugüne İstanbul Ansiklopedisi, vol. 7, pp. 360-362.

95. This mosque had been built during the reign of Suleyman I. Due to several fires, Abdülhamid II reconstructed it in 1899. Its muvakkithane might have been built during this reconstruction. See Hakan ARLI, “Cihangir Camii”, Dünden Bugüne İstanbul Ansiklopedisi, vol. 2, p. 431.

96. This list does not include clock towers and façade clocks planned to be erected. 